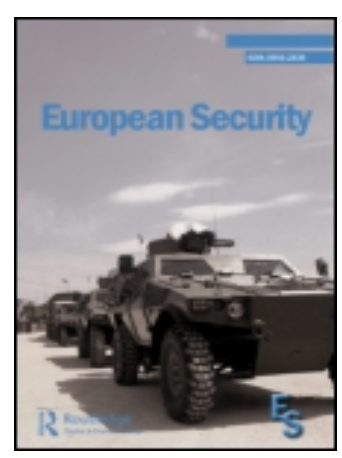

European Security

\title{
Isn't it Time to Say Farewell to Nukes in Turkey?
}

\section{Mustafa Kibaroglu}

To cite this article: Mustafa Kibaroglu (2005) Isn't it Time to Say Farewell to Nukes in Turkey?, European Security, 14:4, 443-457, DOI: 10.1080/09662830500528294

To link to this article: https://doi.org/10.1080/09662830500528294

央 Published online: 24 Jan 2007.

Submit your article to this journal $\pi$

III Article views: 91 


\section{Isn't it Time to Say Farewell to Nukes in Turkey?}

\section{MUSTAFA KIBAROGLU}

ABSTRACT The attitude of Turkish officials toward the US nuclear weapons deployed in Turkey for over four decades has been static. Officials have understandable arguments, based on their threat analysis, as to why these weapons should be retained in Turkey. However, since the 9/11 terrorist attacks, the international security environment has undergone radical changes. The classical deterrent value of nuclear weapons no longer applies with these emerging threats. At the same time, there is an increased probability of unauthorized use of crude radiological devices or nuclear weapons by terrorist organizations. In addition to increased security at storage sites, bolder steps must be taken by concerned countries to get rid of nuclear weapons. Such steps should begin with drawingdown US nuclear weapons deployed in allied countries including Turkey.

\section{Introduction}

The sub-strategic and tactical nuclear weapons deployed in Turkey have become a topic of public debate even though they have never been part of the official discourse. ${ }^{1}$ There are differing views among Turks extending from outright opposition to their presence on Turkish territory, to appreciation of their deterrent capability against actual and potential rivals in the region, especially in the Middle East. Turkish officials have always been careful to make no official public statements on the existence of nuclear weapons in Turkey, or to comment on their role in Turkey's security. Turkish officials maintain that, even though the nuclear weapons play an essential role in NATO's military strategy, the ambiguity principle should apply regarding their status. Therefore, officials suggest, 'when asked about the presence of US nuclear weapons in the territory of NATO allies in general, and in Turkey in particular, the answer would be neither to deny nor to confirm.'2 Notwithstanding the silence of officials, experts in the field who have access to various reliable sources discuss the current and future status of nuclear weapons deployed in Turkey. ${ }^{3}$ It is reported that there are in total some 90 nuclear (gravity) bombs kept at the Incirlik base near Adana on Turkey's eastern

Correspondence Address: Mustafa Kibaroglu. Email: kibar@bilkent.edu.tr 
Mediterranean shore, and in the Murted Air base of the Turkish Air Force in the environs of Ankara. ${ }^{4}$

Hence, this paper aims to discuss the role that US nuclear weapons have played in Turkey's security both throughout the Cold War period and in its aftermath, and why this role must be terminated. Accordingly, the paper will first discuss the reasons why Turkey originally agreed to host US nuclear weapons on its soil in the early 1960s despite the ensuing delicate situation in its relations with the neighboring Soviet Union. Then a section will be devoted to explaining Turkey's position with regard to the universal arms control and disarmament agreements and similar multilateral initiatives. In this context, Turkey's general stance vis-à-vis the nuclear strategies of NATO will also be highlighted. A discussion will follow about the reasons why Turkish officials wanted to retain the US nuclear weapons in Turkey after the disintegration of the Warsaw Pact and the collapse of the Soviet Union; at this time most of them were withdrawn from the territories of other NATO allies. ${ }^{5}$ Finally, the paper will discuss the reasons why the US tactical nuclear weapons should now be withdrawn from Turkey.

\section{The Role of US Nuclear Weapons in Turkey's Security}

After the creation of NATO with the signing of the Washington Treaty on 4 April 1949, the US vigorously supported Turkey's desire for membership. The Americans believed that, due to its geographical location, Turkey could play a very important role in their strategic vision for the post-Second World War period. However, Western European allies were not equally enthusiastic about the idea. The defense of Turkey was the key issue of contention between Europeans and Americans as they did not have identical lists of enemy states against which the allied territories would have to be defended. No country is explicitly cited in the text of the Washington Treaty as the 'enemy' of NATO. ${ }^{6}$ However, Article 6 of the Treaty delineated the territory that would have to be defended collectively against attacks from outside; the Soviet Union and its satellite countries were implied as the potential aggressor(s) at that time.

Whereas the Europeans were mainly concerned about the Soviet threat, the American concern was much wider, encompassing countries in the Middle East, especially those hostile to Israel. When the US suggested preparing contingency plans encompassing the Persian Gulf region, the West European members of NATO generally opposed the idea as the threat perceived from Eastern Europe was of primary importance for them. In other words, the Middle East was 'out-of-area' of their defense commitment. ${ }^{7}$ Turkey, on the other hand, was a member of the Western camp, but having neighbors like Syria, Iraq and Iran (after the Islamic revolution) prompted it to closely watch the security situation in the Middle East. There were basically three reasons for the divergence of views within the Alliance vis-à-vis the Middle East. First of 
all, countries like Syria and Iraq were not posing a serious threat to the Western European members of NATO, even though they had had intensive relations with the Soviet Union since the 1970s. Secondly, most of the countries in the region were either actual or potential trade partners of Western European countries. A third factor was the degree of historical relations between the Middle Eastern countries and the key European allies.

The European members of NATO had no desire to be put in a quandary because of an ally's (Turkey's) conflict with its southern neighbors; such a conflict could eventually escalate into a superpower rivalry and nuclear exchange that could devastate all of Europe. Therefore, in informal gatherings, leading European members of NATO have made it clear, time and again, that their loyalty to the Article 5 commitment (alliance solidarity) of the Washington Treaty would cover only these situations where Turkey had to be defended against its northeastern neighbor, namely the Soviet Union. $^{8}$

The discrepancy between the views of Europeans and Americans concerning 'which territory to defend against whom' has been lingering on within the Alliance since Turkey's membership in 1952. Due to the selective attitude of the European allies in matters pertaining to the defense of Turkey, it was the Americans who most of the time prevailed in the debates within the Alliance on these matters. As such, for many Turks NATO meant the US and vice versa, and Turkish-American relations evolved as an alliance within the Alliance throughout the Cold War. ${ }^{9}$

When Turkey joined NATO, the parties tacitly agreed that the Turks would help contain the Soviet Union. Should deterrence fail, Turkey would have made its facilities available to NATO and would have distracted as many Soviet forces as possible from a campaign in Central Europe. ${ }^{10}$ The military thinking of the Alliance focused on the central front as the main area of the Soviet/Warsaw Pact threat, putting an overwhelming emphasis on the contingency of a massive attack through Germany into Western Europe. ${ }^{11}$ Therefore, defending Turkey would be vitally important to the Europeans as it would retard, or even prevent, a powerful Soviet assault on Western Europe. Indeed, as a NATO ally, Turkey risked its own devastation by virtue of its location in the immediate neighborhood of the Soviet Union.

During the 1960s and well into the 1970s, the Soviet threat was felt more explicitly both in Turkey and in the US as the Soviet Union closed the gap with the US in the nuclear arms race. The Soviets increased their military presence and capabilities in conventional and unconventional weaponry along Turkey's eastern frontier as well as their naval presence in the Mediterranean. That period also witnessed intensifying relations between the Soviets and Syria in all respects, including the military field. The Soviet Union's growing military presence both in quantitative and qualitative terms across the southern flank of NATO prompted the Alliance in general and Turkey in particular to rely extensively (though gradually) on nuclear forces. 
The Washington Treaty did not involve specific requirements for the member states regarding the deployment of nuclear weapons. The Turkish political and security elite considered these weapons to be a credible deterrent against the Warsaw Treaty Organization (the Warsaw Pact) in general, and the huge military might of the Soviet Union in particular. Hence, nuclear weapons were deployed according to the mutual commitments of Turkey and NATO. ${ }^{12}$

Fully aware of the overwhelming superiority of the Warsaw Pact countries in conventional weapons systems, Turkey opposed the proposal to establish a nuclear weapons-free zone (NWFZ) in the Balkans. The proposal for a nuclear weapons-free Balkans was first put forward by the Soviet Union on 25 June 1959, when the deployment of US medium range nuclear missiles to Turkey was on the horizon. The Soviets initiated counter-measures at the international level, and 'recommended' to the Turks that they not accept these weapons, which could hit targets in the Soviet Union and would therefore be targeted by the Soviet nuclear missiles. But Turkey did not give in to the Soviet threats.

The non-deployment or removal of nuclear weapons from Turkey would expose the country to a very difficult military situation. For Turkey, the existence of nuclear weapons on its soil meant the active presence and full backing of NATO and the US in contingency plans involving the Warsaw Pact countries. Hence, Turkish officials did not support the idea of establishing a nuclear weapon-free Balkans even though this proposal had political advantages for some countries in the region because of the opportunities it presented to conduct 'high politics' with the help of disarmament rhetoric. ${ }^{13}$

\section{Turkey and Arms Control and Disarmament Agreements}

Even though nuclear weapons have been deployed in Turkey for nearly half a century, the fundamental thrust of Turkish foreign and security policy has been to become a state party to international nuclear arms control and disarmament agreements. Turkey signed the Nuclear Non-Proliferation Treaty (NPT) on 28 January 1969, and subsequently ratified it on 17 April 1980. Turkey's rather late ratification of the NPT may raise the question of whether Turkish politicians wanted to keep the nuclear option open. The conventional wisdom suggests that this is unlikely. However, the traditional influence of the military on matters relating to national security was probably a factor that delayed ratification. During the 1970s, there was a growing interest in nuclear and other weapons of mass destruction in neighboring countries like Iran, Iraq, and Syria; at that time the Turkish military might not have wanted to give the impression, by means of a hasty ratification, that Turkey would definitely forgo the nuclear option. Although they had no real nuclear intention, Turkish 
officials wished to leave the issue ambiguous as a deterrent against regional rivals and enemies.

Other factors in Turkey should also be mentioned. In the second half of the 1970s, Turkey went through a period of chaos ending in the military intervention of 1980; many political analysts feel this rescued the country from the brink of an all-out civil war. Ratification of the NPT was not a priority for the Turkish Grand National Assembly at a time when the country was struggling with anarchy and there was no non-proliferation culture. In addition to this, the nuclear infrastructure of Turkey was not significant. Two small-scale nuclear research and training reactors were probably not considered by policymakers as compelling reasons for speeding up the ratification process that would then require Turkey to conclude a safeguards agreement with the International Atomic Energy Authority (IAEA).

In line with its general stance toward international arms control and disarmament initiatives, Turkey has also become state party to the Biological Weapons Convention of 1972 by ratifying it in November 1974. Turkey signed the Chemical Weapons Convention of 1993 that was followed by its ratification by the Turkish Grand Assembly in April 1997. Moreover, Turkey has taken several steps, especially since the mid-1990s, to become a member of the Nuclear Suppliers Group (NSG); this finally happened in June 2000. ${ }^{14}$ Turkey has also speeded up the process of adjusting its national export control regime (i.e., laws and regulations) to that of the NSG countries. Turkey has undertaken the same stance toward the Zangger Committee and became a member almost as an automatic outcome of formal accession to the NSG. ${ }^{15}$ Turkey also became a member of the Missile Technology Control Regime (MTCR) in April 1997, which aims to demonstrate to actual and potential proliferants that there is a solid block of like-minded nations which are unified in their determination to fight proliferation. ${ }^{16}$

Turkey also signed the Comprehensive Test Ban Treaty (CTBT) in 1996 and ratified it in 2000. It is one of 44 states whose ratification was necessary for the treaty to become effective because it has two small nuclear research reactors. As a member of the Conference on Disarmament, 'Turkey is pleased to have joined the overwhelming majority of nations in the effort to conclude a CTBT. ${ }^{17}$ The complete ban on nuclear testing, the core function of the Treaty, is thought by the Turkish officials to be an effective measure to control nuclear weapons technology and an important step towards the eventual elimination of nuclear weapons.

Turkey never sought to acquire weapons of mass destruction; it also contributed to international efforts to strengthen the non-proliferation regime and participated actively in the process of enhancing the IAEA's verification system with a view to making the safeguards inspections more stringent. As for the Additional Protocol that was released by the IAEA as a result of 'Programme 93+2'; Turkey ratified the document in July 2000. ${ }^{18}$ Indeed, following the adoption of the Protocol, there were some concerns among 
policymakers in Turkey that the right of access given to IAEA inspectors would be virtually unlimited, leading to UNSCOM-like applications in chosen countries. Diplomatic negotiations led to the resolution of potential problem areas and ratification was granted.

\section{Turkey and the Nuclear Strategy of NATO}

From a general perspective, Turkish officials view the abolition of nuclear weapons as a noble aim, one that should stay on the agenda. However, officials argue that the international context requires them to acknowledge that this aim can only be reached in stages. Moreover, Turkey endorses NATO's 'first-use' strategy, which has been in effect, at least on paper, since the first decisions taken within the Nuclear Planning Group of the Alliance. In order to avoid any confusion or misinterpretation of the terms, Turkish officials emphasize that NATO's 'first use' strategy does not imply 'pre-emptive use', which means the use of nuclear weapons before any aggression occurs. Rather, 'first-use' implies that NATO may be the first to use nuclear weapons during an aggression, if no other option can provide a better way of defending the allies against the aggressor(s).

When the Soviet Union declared in 1982, as part of a peace offensive, that it would not be the first to resort to nuclear weapons and initiated a 'no-first-use' strategy, Turkey considered the Soviet pledge to be a mere propaganda tool. During the East-West rivalry, NATO countries relied on their nuclear capability to offset the superiority of the Warsaw Pact countries in conventional weaponry. ${ }^{19}$ Because it was envisaged that NATO might not win a war without resorting to nuclear weapons, whereas the Warsaw Pact countries might, with their conventional superiority.

In the aftermath of the disintegration of the Soviet Union, even though simple logic might have suggested that NATO with its indisputable superiority in conventional forces might have adopted the 'no-first-use' strategy. But things were not so simple. NATO had a number of constraints as far as the threat of proliferation of WMD, especially in the Middle East was concerned. In the mid-1990s, it was anticipated that European capitals would soon be within the range of ballistic missiles from the Middle East, and that the southern members of NATO would be the first to feel the political and military consequences of proliferation trends on Europe's periphery. ${ }^{20}$ Therefore, in June 1996, NATO foreign and defense ministers endorsed a comprehensive approach to counter the military risks posed by such threats. ${ }^{21}$ NATO's efforts to adapt itself to meet the challenges of the new security environment have produced guidelines for appropriate responses to proliferation. The overarching principles were determined to be to 'maintain freedom of action and demonstration to any potential adversary that the alliance will not be coerced by the threat or use of WMD. ${ }^{22}$ 


\section{Contending Views on Draw-Down of US Nukes from Turkey}

Dramatic changes have taken place in the international security environment over the last decade. These changes, however, are being assessed differently among officials and experts regarding the role of nuclear weapons. The viability as well as the credibility of the nuclear posture of NATO, including the implicit 'first use' strategy of the Alliance, is still of utmost importance for Turkish officials. ${ }^{23}$ However, the very nature of the emerging threats, especially since the $9 / 11$ attacks, requires a thorough revision of the ways and means of dealing with them. Admittedly, nuclear weapons have become inappropriate in the face of the new threats posed to the free world by terrorist organizations. Retaining them simply increases the probability of theft and the use by terrorists of some crude radiological devices or even nuclear weapons.

Therefore, in addition to taking tighter measures to safeguard nuclear and radiological material in places where they are stored, bolder steps must be taken by concerned countries to ultimately get rid of nuclear weapons. Such steps should begin with drawing-down the US nuclear weapons deployed in allied countries overseas including Turkey. Nevertheless, the official view is diametrically opposed to their withdrawal. Below is an account of why this is the case.

\section{'Nukes Should Stay'}

Turkish officials consider nuclear weapons more as political weapons than as having a significant military value; they do not seriously think of contingencies where nuclear weapons could or even should be used. Having said that, they do believe in the deterrent value of US nuclear weapons stationed in Turkey. It is true that the Middle East and adjacent regions are far from being peaceful or stable; this situation is unlikely to change soon. Adding to the unrest arising from the political situation in Iraq, and the Palestine-Israel conflict, is Iran's substantial nuclear development program that may have weapons development potential. Uncertainty about Iran's capabilities as well as its intentions further complicate threat assessments by Turkish officials. Hence, retaining US nukes in Turkey 'to be on the safe side' sounds like a better option to them.

However, the fundamental reason why Turkish officials want to keep the weapons has more to do with the nature and the scope of Turkish-American relations in particular, and Turkey's place in the Western alliance in general. First and foremost, the deployment of the remaining tactical nuclear weapons in Turkey is believed to strengthen the bonds between the US and Turkey; these bonds were severely strained during and after the crisis in Iraq in late 2002 and neither party got what it wanted. ${ }^{24}$ Withdrawing the US nuclear weapons from Turkey during such a delicate period could weaken the bonds in the longstanding strategic alliance (or the 'partnership' as many Turkish and American analysts would prefer to term it). 
Turkish officials also see the deployment of these weapons as part of the 'burden sharing' principle within the Alliance. They would prefer that some other allies also continue to host US nuclear weapons on their soil, if only in symbolic numbers. Then Turkey would not stand out as the only country in NATO that retains US nuclear weapons in Europe. Reportedly, there are some 480 tactical US nuclear weapons that are still deployed in a handful of NATO allies. ${ }^{25}$ The significance of retaining American nuclear weapons in Europe is said to be to 'anchor the US to the Continent' especially in an age when the transatlantic ties are seemingly weakened due to the diverging views over the US war on Iraq. Otherwise, it is feared that the 'isolationist' view and those who advocate the idea of 'disengagement' in the US may have the upper hand in American domestic politics. It is believed that such an eventuality could cause further deterioration in transatlantic relations, and might not make either side better off politically, economically or militarily.

Having expressed their desire to keep US nuclear weapons in Turkey at the expense of the political and economic burden attached to them, Turkish officials also point out a serious concern regarding the true desire of the American administration. They worry that the US may have secretly developed (or may be in the process of developing) new weapons systems, which may not necessitate overseas deployment. Should this be the case, Turkish officials fear that the solidarity principle may be seriously hurt and the Alliance may lose its spirit and its 'raison d'être'. ${ }^{26}$

\section{'Nukes Must Go'}

The above-cited views of Turkish officials contain very valid points in explaining why Turkey has long favored the deployment of US nuclear weapons and still wants to keep them. However, any discussion of nuclear weapons must also incorporate a description of the peculiarities as well as the possible effects of these weapons. Whether it is about the proliferation of weapons of mass destruction in the Middle East; or nuclear arms reduction treaties between the US and the Russian Federation; or the implications of a draw-down of US tactical nuclear weapons from the territories of NATO allies, such discussions mostly revolve around the notion of deterrence as well as the nature of bilateral relations with the US.

It is true that nuclear weapons are the most powerful weapons so far invented and developed by mankind. However, nuclear weapons may have unprecedented consequences for mankind as well as the environment if and when they are used deliberately or accidentally. ${ }^{27}$ Thus, approaching the nuclear weaponsrelated issues merely from the perspective of the concept of balance of power or the notion of deterrence would be both incomplete and misleading. Even the civil or military leaders, who have the authority to resort to nuclear weapons if deterrence based on the threat of use of these weapons fails, may not necessarily have a clear idea about the catastrophic consequences of their decision. 
Nuclear weapons were used for the first - and hopefully the last - time in wartime conditions on 6 and 9 August 1945 in Hiroshima and Nagasaki by the US. $^{28}$ Since then, nuclear and thermo-nuclear weapons that are thousands of times more powerful than the ones used against Japan have been produced and stockpiled by a number of states. ${ }^{29}$ Over time, both the types and the delivery platforms of nuclear weapons have become more diversified.

Then the so-called 'second-strike capabilities' of the superpowers were developed; this maintained stability during the Cold War. It was virtually impossible for one of the parties to launch a surprise attack with a view to disarming the other. Well-protected nuclear stockpiles, multi-megaton-yield nuclear warheads on long-range missiles in nuclear submarines, strategic-range bomber aircraft and ground-based ICBMs that could reach each others' strategic assets (both military and civilian) reduced the likelihood of war almost to zero. Since it was impossible to fight, the parties had to deter each other. Since the world has seen the effects of the 'primitive' nuclear weapons that were detonated in Hiroshima and Nagasaki, the fear of a nuclear catastrophe served well the purpose of a perfect deterrent during the Cold War. ${ }^{30}$

However, the sui generis conditions of the superpower rivalry during the Cold War period cannot be used as a pretext for keeping the existing stockpiles of nuclear weapons or for developing new ones when the international security environment is undergoing dramatic changes. The perception of threat to states has been subject to thorough revision especially in the aftermath of the $9 / 11$ attacks on the US. Almost every state has started to seriously consider how to deal with the threat posed by the so-called 'non-state actors' which are believed to have the capability to build weapons of mass destruction or to have unauthorized access to ready-made weapons of that sort. $^{31}$

Therefore, it becomes more and more irrelevant to consider nuclear weapons as a symbol of prestige or national pride, or as a perfect deterrent against other states. The probability of use of elaborate or crude nuclear devices by states or non-state actors increases as more and more actors on the world political stage have the capability and/or the intention to build such weapons. To avoid a nuclear catastrophe in the future, every nation must start thinking about effective ways of getting rid of the remaining nuclear weapons or further limiting their numbers and deployment sites. These steps must be taken regardless of previously held policies in order to prevent the acquisition of nuclear weapons by terrorist organizations which may use them with no thought for the consequences. Fewer pretexts or justifications may be created for new states to aspire de facto nuclear weapons status.

\section{Conclusion}

Against this background, Turkish officials should start acknowledging the need for action with respect to the US nuclear weapons deployed in Turkey. 
Extended reliance on the presence of these weapons to defend the country may lead to missing some opportunities to take region-wide initiatives such as revitalizing the efforts to create a nuclear weapons-free zone in the Middle East (NWFZ/ME). Notwithstanding Turkey's opposition to a Balkan NWFZ for reasons explained earlier in this paper, Turkey fully supported a proposal that aimed at establishing such a zone in the Middle East; this was originally cosponsored by Egypt and Iran as early as 1974. Turkey also expressed its concern that such a zone should encompass all kinds of weapons of mass destruction as well as their means of delivery.

One principal reason for supporting the idea of a NWFZ/ME was the threat posed by the spread of nuclear, chemical and biological weapons of mass destruction into the Middle East. Since Turkey was confident that its conventional arsenal could cope with its Middle Eastern neighbors, any proposal that would eliminate the non-conventional capabilities of these states would increase Turkey's security. However, because Turkey was hosting US nuclear weapons, Turkish officials did not consider becoming part of the zone. Realistic enough, other countries in the region did not insist on having Turkey on board either, if and when such a zone ever became possible.

However, the tide is turning, and since the early 1990s Turkey is getting more and more involved in Middle Eastern politics. Apart from Turkey's attempts to become a facilitator in the Israeli-Palestinian dispute, Turkey finds itself at the core of the developments in Iraq. As such, other countries in the region are also reconsidering Turkey's position vis-à-vis Middle Eastern politics. Complaints have been heard from regional analysts regarding Turkey's alliance with the US and Israel. When Turkish scholars and authorities comment on Iran's nuclear program, their Iranian counterparts point out that US nuclear weapons are still deployed in Turkey. Some even go so far as to qualify Turkey as a 'nuclear weapons state', although such a status is not compatible with the definitions in the Non-Proliferation Treaty. ${ }^{32}$ This expression of how Turkey is seen by the Iranian authorities serves as another justification for Iran's ambitions to develop nuclear weapons. It is highly likely that 'Iran has developed the basic infrastructure to detonate a nuclear device. ${ }^{33}$ Should the Iranian leadership decide to develop nuclear warheads in the years to come, neither the Middle East nor the world will become a safer place to live. Most probably, some other countries in the region such as Egypt and Saudi Arabia would follow suit. Countries in other parts of the world may do so as well.

Iran's strategy may be to develop 'break-out' capabilities by staying in the Treaty for some time and then walking out with a unilateral declaration of its withdrawal, possibly with a small nuclear arsenal in stock. ${ }^{34}$ Such an eventuality may also lead to the collapse of the nuclear non-proliferation regime. Therefore, preventing Iran from going down that path is crucial and requires taking timely action. One possible action, taken to free the Middle East from all sorts of weapons of mass destruction, might be to ask all the states to agree to a NWFZ/ME (in return for security guarantees). ${ }^{35}$ These 
security guarantees could encompass all the countries in the region, including Turkey and Israel (where nuclear weapons are deployed, even though they have never been formally acknowledged).

That said, any negotiations regarding the draw-down of nuclear weapons in Turkey should be very carefully handled so as not to create confusion in the minds of Turkish officials regarding the true intentions behind such an initiative. There are basically two caveats to this proposal. First, most Turkish officials still resent what happened during the Cuban missile crisis. ${ }^{36}$ They see the nuclear weapons in Turkey as an integral part of the country's security and they are unlikely to trade off their deployment as part of a bargain with the Iranians to stop developing their nuclear weapons capability. As a foreign policy principle, regardless of the context, Turkish officials are not at all sympathetic with the idea of being part of a deal beyond their control. Secondly, Iranians may well not be satisfied with the offer, if and when it is proposed. It seems that Iran's desire 'to be admitted to the nuclear club' is an overarching goal and is not solely related to their perception of threat from the US nuclear weapons deployed in Turkey. Most Iranians consider the idea of developing nuclear weapons as a function of their national pride and prestige. $^{37}$

However, these should not be seen as insurmountable difficulties provided that the US also starts seriously drawing down its own nuclear arsenal; it also must put off the projects in the pipeline for developing new, ever more sophisticated nuclear weapons that were to assure its nuclear supremacy in the decades to come. The whole notion of national security and national interest must be overhauled in the face of a series of tragic attacks on civilians in all parts of the world. These attacks suggest even more deadly scenarios were the terrorist organizations to equip themselves with nuclear explosives. Perhaps they have already done so. If the family of sovereign nations is lucky, there may be enough time to implement a number of sober-minded steps that will get rid of the existing nuclear weapons, wherever they may be deployed or stockpiled.

\section{Notes}

${ }^{1}$ This issue is discussed, among others, on some television channels such as the leading Turkish news channel NTV on 9 December 2004, with the participation of retired generals, ambassadors and academics, upon the circulation of news in Turkish media based on a story that was published earlier in the November/December 2004 issue of The Bulletin of the Atomic Scientists. See for details http://www.ntvmsnbc.com. Also see http://www.thebulletin.org.

${ }^{2}$ Although it is possible to cite names here, no specific references will be made in the text to officials with whom the author has conducted interviews or exchanged views in various meetings over the last decade for the sake of being true to the general principle of non-attribution in such sensitive issues.

${ }^{3}$ The author has done extensive research on a variety of topics relating to the proliferation of weapons of mass destruction as well as arms control and disarmament. This article is the 
culmination of his observations about the issues that have come up during the meetings that he attended with experts and officials from various academic and bureaucratic circles in Turkey.

${ }^{4}$ See the 'Nuclear Notebook' provided by the Natural Resources Defense Council on 'US Nuclear Weapons in Europe, 1954-2004', The Bulletin of the Atomic Scientists 60/6 (November/December 2004) pp. 76, 77.

${ }^{5}$ In 1991, NATO decided to reduce its land-based nuclear stockpile in Europe by 80 percent, and this reduction was completed by 1993. See, 'Focus on NATO: Facts on NATO's Nuclear Posture', NATO Review No. 4 (July 1996) p. 19.

${ }^{6}$ This is also one of the arguments that is put forward by the proponents of NATO as to why the Alliance survived even after the Warsaw Pact and the Soviet Union collapsed. NATO countries now confront new challenges, which a pose considerable threat to their Western style democracies and the open market economies.

${ }^{7}$ Interview with Gen. Cevik Bir (Ret.), Second Chief of Turkish General Staff, 19 January 2005, Ankara, Turkey.

${ }^{8}$ Interview with Mr. Seyfi Tashan, Director of the Turkish Foreign Policy Institute, 17 May 2004, Bilkent University, Ankara, Turkey.

${ }^{9}$ Notwithstanding, Turkey and the US also had troubled periods in their relations due to President Johnson's letter to Ankara in June 1964, and the arms embargo lasting several years that was imposed by the Carter administration in 1975. Both incidents came as reactions to Turkey's military interventions in Cyprus. But overall, Turkey and the US managed to have quite warm and cooperative relations over the years since they both knew that they would be better off if they collaborated closely. See Mustafa Kibaroglu, 'La Turquie, les États-Unis et l'OTAN: une alliance dans l'Alliance', Questions Internationales 12 (March/April 2005) pp. 30-32.

${ }^{10}$ See Bruce R. Kuniholm, 'Turkey and the West', Foreign Affairs 70/2 (1991) p. 41.

${ }^{11}$ See Ali L. Karaosmanoglu, 'Europe's Geopolitical Parameters', in Subidey Togan and V.N. Balasubramanyam (eds), Turkey, Central and Eastern European Countries in Transition (New York: Palgrave Press 2001) pp. 271-89. Also see Mustafa Kibaroglu, 'Turkey', in Harald Müller (ed.), Europe and Nuclear Disarmament (Brussels: European Interuniversity Press 1998) pp. 16193.

${ }^{12}$ At the NATO meeting in Washington, DC in December 1957, it was decided to deploy longrange ballistic missiles in Europe. Around 1960, US Thor and Jupiter missiles became operational in the UK, Italy and Turkey. They had a range of approximately $3,000 \mathrm{~km}$ and a warhead yield of 1.5 megatons. Jupiters in Italy (30) and in Turkey (15) were phased out by 1965 . See, World Armaments and Disarmament SIPRI Yearbook 1982 (London: Taylor \& Francis Ltd, for Stockholm Peace Research Institute 1982) p. 7.

${ }^{13}$ For instance, Greece, despite the fact that it was a NATO ally, not only welcomed the idea of a Balkan NWFZ but also became a co-sponsor of subsequent proposals. See N. Behar and I. Nedev, 'A Nuclear Weapon-Free Zone in the Balkans', in Sverre Lodgaard and Marek Thee (eds), Nuclear Disengagement in Europe (London: Taylor \& Francis 1983) pp. 93-8.

${ }^{14}$ The Nuclear Supplier Group has reproduced a set of guidelines that most of the suppliers of nuclear plants and materials agreed to in London on 21 September 1977. That is why this group is also known as the London Club. This set of guidelines is also attached to a communication addressed on 11 January 1978 to the Director-General of the IAEA. These guidelines for nuclear transfer are also labeled INFCIRC/254. The initial signatories of the guidelines are Belgium, Canada, Czechoslovakia, France, the former German Democratic Republic and the Federal Republic of Germany, Italy, Japan, the Netherlands, Poland, Sweden, Switzerland, the UK, the USA and the USSR.

${ }^{15}$ The Zangger Committee named for its Swiss chair Prof. Claude Zangger, and the Nuclear Suppliers Group shared in common the purpose of limiting the transfer of significant material and technology to states that are suspected of being engaged in clandestine nuclear weapons manufacturing.

${ }^{16}$ The Missile Technology Control Regime is an informal, non-treaty association of states that have an established interest in limiting the spread of missiles and missile technology. According to the 
guidelines, the MTCR's original purpose was to reduce the risks of nuclear proliferation by placing controls on equipment and technology transfers, which contribute unmanned nuclear weapons delivery vehicles. The MTCR puts limitations on member countries' export of missiles with a range of $300 \mathrm{~km}$ and a payload of $500 \mathrm{~kg}$.

${ }^{17}$ Ad hoc conversations with Turkish diplomats.

${ }^{18}$ Effective inspections carried out in Iraq under UN Security Council Resolution 687 have led to debate concerning whether the broad, but previously unexercised, rights of the IAEA under basic NPT safeguards agreements could not be used to carry out inspections beyond the routine inspections directed toward known declared activities. After examining this issue, the Secretariat of the IAEA concluded that this right had indeed existed all along, and the Board of Governors in February 1992 agreed with this finding. By the same token, throughout the 1990s, the IAEA has focused extensively on measures to make the safeguards system more effective and efficient. The major effort in this undertaking is called 'Programme 93+2', the IAEA's program to develop and test a comprehensive set of measures to improve safeguards implementation. The formal title of the program is 'Strengthening the Effectiveness and Improving the Efficiency of the Safeguards System'. The program formally began with the IAEA Board of Governors' endorsement of the proposed effort in December 1993 and finished in December 1995. See, in this respect, Mustafa Kibaroglu, 'Turkey's Sweet and Sour Policy Against WMD Proliferation', Turkish Policy Quarterly 3/2 (Summer 2004) pp. 101-11. The document of ratification was published in the Official Gazette on 16 July 2001 in its 24460th issue.

${ }^{19}$ It was generally estimated that the Warsaw Pact countries had some 50 percent superiority over NATO countries in overall conventional weapons capability.

${ }^{20}$ See Ronald D. Asmus, F. Stephen Larrabee and Ian O. Lesser, 'Mediterranean Security: New Challenges, New Tasks', NATO Review 3 (May 1996) pp. 25-31.

${ }^{21}$ This issue was explicitly cited in Communique (29) released after the meeting of the North Atlantic Council in Defense Minister Session, on 13 June 1996. For full documentation, see NATO Review 5 (September 1996) pp. 32-5.

${ }^{22}$ See Ashton B. Carter and Davis B. Omand, 'Countering the Proliferation Risks: Adapting the Alliance to the New Security Environment', NATO Review 5 (September 1996) pp. 10-15.

${ }^{23}$ See Ali L. Karaosmanoglu and Mustafa Kibaroglu, 'Defence Reform in Turkey', in Istvan Gyarmati and Theodor Winkler (eds), Post-Cold War Defense Reforms: Lessons Learned in Europe and the United States (New York: Brassey's 2003) pp. 135-64.

${ }^{24}$ See Mustafa Kibaroglu, 'Turkey Says No', The Bulletin of the Atomic Scientists 59/4 (July/August 2003) pp. 22-5. Also see Mustafa Kibaroglu, 'Missing Bill Clinton', The Bulletin of the Atomic Scientists 60/2 (March/April 2004) pp. 30-32.

${ }^{25}$ See Hans M. Kristensen, US Nuclear Weapons in Europe: A Review of Post-Cold War Policy, Force Levels, and War Planning (Washington, DC: Natural Resources Defense Council, February 2005) p. 9.

${ }^{26}$ In the context of a research project on 'Turkey and Nuclear Disarmament' carried out in Monterey, California back in February 1997, then Turkish Ambassador to Ottawa, Mr. Omer Ersun clearly stated to the author in a telephone interview that 'NATO without the US nuclear weapons deployed in Turkey would mean nothing to the Turks'.

${ }^{27}$ See in these respects, for example, Bruce G. Blair, The Logic of Accidental War (Washington, DC: The Brookings Institution 1986); Joseph S. Nye, Jr, Nuclear Ethics (New York: The Free Press 1986); Avner Cohen and Steven Lee (eds), Nuclear Weapons and the Future of Humanity (New Jersey: Rowman \& Allenheld Publishers 1986); Marc A. Harvell and Thomas C. Hutchinson (eds), Environmental Consequences of Nuclear War, Volume I, Physical and Atmospheric Effects (New York: John Wiley \& Sons 1986); Marc A. Harvell and Thomas C. Hutchinson (eds), Environmental Consequences of Nuclear War, Volume II, Ecological and Agricultural Effects (New York: John Wiley \& Sons 1986); Eric R. Merc and Carl Walter (eds), Disposal of Weapons Plutonium: Approaches and Prospects (Boston: Kluwer Academic Publishers 1996).

${ }^{28}$ It was reported that the HEU-based Hiroshima bomb that was called 'little boy' yielded energy equivalent to an explosion of 16 kilotons of TNT (dynamite), whereas the plutonium-based 
Nagasaki bomb called 'fat man' yielded energy equivalent to 20 kilotons of TNT. Considering that ordinary long-distance trucks can carry approximately 10 tons of any freight, the explosion that devastated Nagasaki could be achieved by bringing 2,000 of such trucks together, each of them fully loaded with 10 tons of TNT, and detonating them at the same moment.

${ }^{29}$ Both the US and the Soviet Union found themselves in a fierce arms race all through the 1950s and 1960s and added hundreds of thermonuclear warheads to their arsenals. The Soviet Union detonated a thermonuclear weapon in October 1961, dubbed the 'Tsar's bomb' which had a yield of 58 megatons. The 'Tsar's bomb' was thousands of times more powerful than the Nagasaki bomb in just one single warhead. Other countries have followed the US (1945) and the Soviet Union (1949): the United Kingdom (1952), France (1960) and the People's Republic of China (1964). These states were later defined as 'nuclear weapons states' by the Treaty on the NonProliferation of Nuclear Weapons (NPT) of 1968 because of the fact that they managed to detonate a nuclear device prior to 1 January 1967 as stated in the text of the Treaty. It is strongly believed that Israel also developed nuclear weapons toward the end of the 1960s. As part of its national security strategy Israel has neither acknowledged nor denied the existence of nuclear weapons in its military arsenal. India, on the other hand carried out a 'peaceful nuclear explosion' in 1974. Later, in 1998, India carried out a series of nuclear explosions followed by its arch-rival Pakistan only weeks later. South Africa declared in 1993 that it had developed 6 nuclear warheads throughout the 1980s and then decided to join the NPT by renouncing nuclear weapons status. North Korea also declared in February 2005 that it had developed nuclear warheads over the last few years. Iran is believed to be technologically very close to assembling a nuclear explosive device.

${ }^{30}$ The use of the term 'primitive' for the bombs that were detonated in Japan should by no means be seen as undermining the severity of the situation that was created there. The purpose is to underline the fact that these were the first atomic bombs used for military purposes, and also they were comparatively much less powerful and less sophisticated than their successors, especially the thermonuclear weapons.

${ }^{31}$ Interview with Ambassador Marc Grossman, US Undersecretary of State, 18 March 2002, Georgetown University, Washington DC, USA.

${ }^{32}$ During a conversation with authorities at the Iranian Center for Strategic Studies in December 2004 in Tehran, Dr. Mahmood Vaezi, the Director of the Center, expressed this view, albeit ironically, to make his country's concerns clear about the US nuclear weapons stationed in Turkey.

${ }^{33}$ Conversations with Iranian scientists, scholars and diplomats in Tehran, Iran who wished not to be identified. December 2004 and March 2005.

${ }^{34}$ Ayetollah Hassan Rohani, Secretary of the Iranian Supreme National Security Council, clearly stated in his opening remarks at the conference on 'Nuclear Technologies and Sustainable Development' in Tehran, Iran on 5 March 2005 that 'should the Iran dossier be passed on to the United Nations Security Council by the Board of the IAEA, Iran would immediately withdraw from the negotiations with the Europeans and would also reconsider its membership status in the Nonproliferation Treaty (NPT).'

${ }^{35}$ See in this respect Mustafa Kibaroglu, 'EURATOM \& ABACC: Safeguard Models for the Middle East?', in Jan Prawitz and James F. Leonard (eds), A Zone Free of Weapons of Mass Destruction in the Middle East (New York: United Nations Institute for Disarmament Research 1996) pp. 93-123.

${ }^{36}$ The Kennedy administration agreed to remove Jupiter missiles from Turkey without consulting its Turkish allies. News leaked, presumably from the Soviet embassy in Ankara, that Kennedy had agreed to a trade-off of the Jupiters during the Cuban crisis without informing the Turks. The removal of the missiles had already served to widen the gap between the right and left in the domain of Turkish domestic politics. The leftists argued that the rightist government sold the country to the Americans. With the revelations in the press about the missile trade-off, antiAmerican and neutralist sentiments grew on the part of liberals and socialists alike. In the military domain, however, things went rather slowly. In 1970, the Turkish government 
announced, after consultations with the military, that the Military Facilities Agreement of 1954 with the US was abrogated. From then on the Turks were able to use the issue of military bases to its own advantage. See Nur Bilge Criss, 'Strategic Nuclear Missiles in Turkey: The Jupiter Affair (1959-1963)', Journal of Strategic Studies 20 (1997) pp. 97-122. Also see Jerrold I. Schecter and Vyacheslav V. Luckhov (eds), Khruschev Remembers: The Glasnost Tapes (Boston: Little, Brown and Co. 1990).

${ }^{37}$ Conversations with Iranian scientists, scholars and diplomats in Tehran, Iran who wished not to be cited. December 2004 and March 2005. 